\title{
Social Ecology of the huemul at Torres Del Paine National Park, Chile
}

\author{
Ecología Social del huemul del Parque Nacional Torres Del Paine, Chile
}

\author{
Gladys Garay ${ }^{1}$, Isaac M. Ortega² \& Oscar Guineo ${ }^{1}$
}

\begin{abstract}
In a ten-year study of the huemul (Hippocamelus bisulcus) population at Torres del Paine National Park in southern Patagonia, we covered a wide range of information regarding the ecology of this endanger deer. We determined the huemul social structure, social behavior, reproductive season, and associated movements throughout the year. Huemuls were observed in the park central area of Sector Grey. When animals were located, natural marks or scars, coloring of body and face, and antler characteristics were used to identify them. We also ear tagged sixteen fawns from 2002 to 2008. Behavioral information was collected from all members with focal observations. We found established and transient social groups. Among the established we found family groups, solo female, and solo male, and among the transient we found solo female, solo male, solo yearling, pair of yearlings, and mixed groups. Family groups were observed throughout the year since they remained in the same area. We observed the first mating of marked females at about 16 months of age. We were not able to determine male age of their first mating, since they left the study site as yearlings. Females gave birth from late October to mid-November. The home range varied from 269 to 336 ha for the established family group. Huemul movements were associated with seasons and reproduction cycles, which also implies group changes. During the rut, some transient solo males tried to move into home ranges of established family groups. During the birthing season, pregnant females remained alone for short periods of time,
\end{abstract}

while yearlings were temporarily expelled from their natal group but remained within the home range, thus sometimes the three members of the group were seen alone. These critical periods increased antagonism among huemuls, generating changes in their group structure. Movements associated with huemul in the park consisted of movements within the home range, seasonal movements, dispersion of the yearlings, and movements during the reproductive period.

\section{Key words:}

Hippocamelus bisulcus, social structure, reproduction, dispersion, Chilean Patagonia.

\section{Resumen}

Este es un estudio de la población de huemules (Hippocamelus bisulcus) del Parque Nacional Torres del Paine, en el sur de la Patagonia, durante 10 años, lo que nos permitió obtener un amplio rango de información de los aspectos socio ecológicos de este ciervo en peligro de extinción. Determinamos la estructura social, las interacciones sociales, etapa reproductiva, y los movimientos asociados a lo largo del año. Los huemules fueron observados en un área central del Sector Grey. Una vez localizados los animales, estos fueron identificados usando marcas

\footnotetext{
1 Paraguaya 126, Punta Arenas, Chile. gladysenviaje@ yahoo.com (GG); guineo.garay@gmail.com (OG).

2 Department of Natural Resources and the Environment, Unit 4087, University of Connecticut, Storrs, CT, 06269.

$\triangle$ morty.ortega@uconn.edu
} 
naturales, cicatrices, color del pelaje y características de la cornamenta en los machos, además de aretes numerados en 16 cervatillos marcados entre el 2002 y el 2008. Se colectó información de comportamiento de los integrantes de los grupos, a través de observaciones focales. Encontramos dos tipos de grupos, los grupos establecidos y los grupos transientes Entre los grupos establecidos encontramos grupos familiares, hembras solas y machos solos, en tanto que entre los grupos transientes encontramos hembras solas, machos solos, juveniles solos, juveniles en pares y grupos mixtos. Los grupos familiares permanecieron en la misma área durante todo el año. El primer apareamiento en hembras marcadas fue a los 16 meses. Los cervatillos nacieron a partir de fines de Octubre hasta mediados de Noviembre. No pudimos determinar la edad del primer apareamiento de los machos, pues los marcados se fueron del área siendo juveniles. Las hembras preñadas permanecieron aisladas por cortos períodos de tiempo durante el nacimiento de cervatillos, en tanto que los juveniles fueron temporalmente expulsados de su grupo, permaneciendo en su rango de hogar, de modo que los tres integrantes del grupo se vieron solos. Estos períodos críticos aumentan el antagonismo entre los huemules, lo cual genera cambios en su estructura. Hubieron cuatro tipos de movimientos o traslados de los animales: dentro de los rangos de hogar, reproductivos, estacionales y de dispersión de los juveniles.

\section{Palabras clave:}

Hippocamelus bisulcus, estructura social, reproducción, dispersión, Patagonia Chilena.

\section{INTRODUCTION}

The huemul (Hippocamelus bisulcus, Molina 1782) is the largest native deer found in Chile and it is considered a national symbol. The species is endangered (Jimenez et al. 2008) with a population ranging from 1,000 to 1,500 dispersed in small populations in Chile and Argentina (Flueck, 2009). Flueck and Smith-Flueck (2006) have a more pessimistic count, estimating the Argentinean huemul population to range between 350 and 600 individuals. In Chile, Drouilly (1983) estimated the population from 350 to 1,000 huemuls distributed from Bio-Bio to Magallanes Region (Vila et al. 2006). There have been no recent estimates of the population in Chile.

Long-term studies on the social structure of huemul are unavailable at this time; only shortterm studies have been published. Some studies have considered groups of one to seven animals in the Chilean Tamango National Reserve (Flueck and Smith-Flueck, 1993) to groups of ten animals in Lago Argentino (Díaz \& Smith-Flueck, 2000). These studies mentioned some activities and behavior of huemul during certain periods of the year or describe specific behaviors, such as behavior during the reproductive season (Colomes, 1978; Rau, 1980; Povilitis, 1983, 1985; Aldridge, 1988; Frid, 1999, Anonymous, 2006).

Collecting long-term information to properly manage an endangered species is necessary to learn about its habitat use and critical social behaviors throughout the year. This is especially true for endangered populations living in protected areas such as national parks or reserves. Managers of these reserves require behavioral knowledge to better accommodate the species, as well as to properly manage tourists to avoid disturbing the normal activities of the huemuls.

This study was conducted in the Torres del Paine National Park, Magallanes, Chile. It is perhaps one of the first long-term research studies, Nov 1999 to Nov 2009, on a huemul population in Chile. The ten-year observations allowed us to cover a wide range of information regarding the socioecology of the huemul at Torres del Paine National Park. We present here aspects of social structure, and social and reproductive behavior of this huemul population. We also include how changing seasons and reproductive behavior affect their social structure and the movements of individuals.

\section{METHODS}

\section{Study area}

The study area is located in the western side of Torres del Paine National Park $\left(51^{\circ} 08^{\prime} \mathrm{S}, 73^{\circ}\right.$ 04'W), in the Magallanes Region of Chile in southern Patagonia. Although we may have had over 60 deer in the area (Guineo et al. 2008), we chose to study 

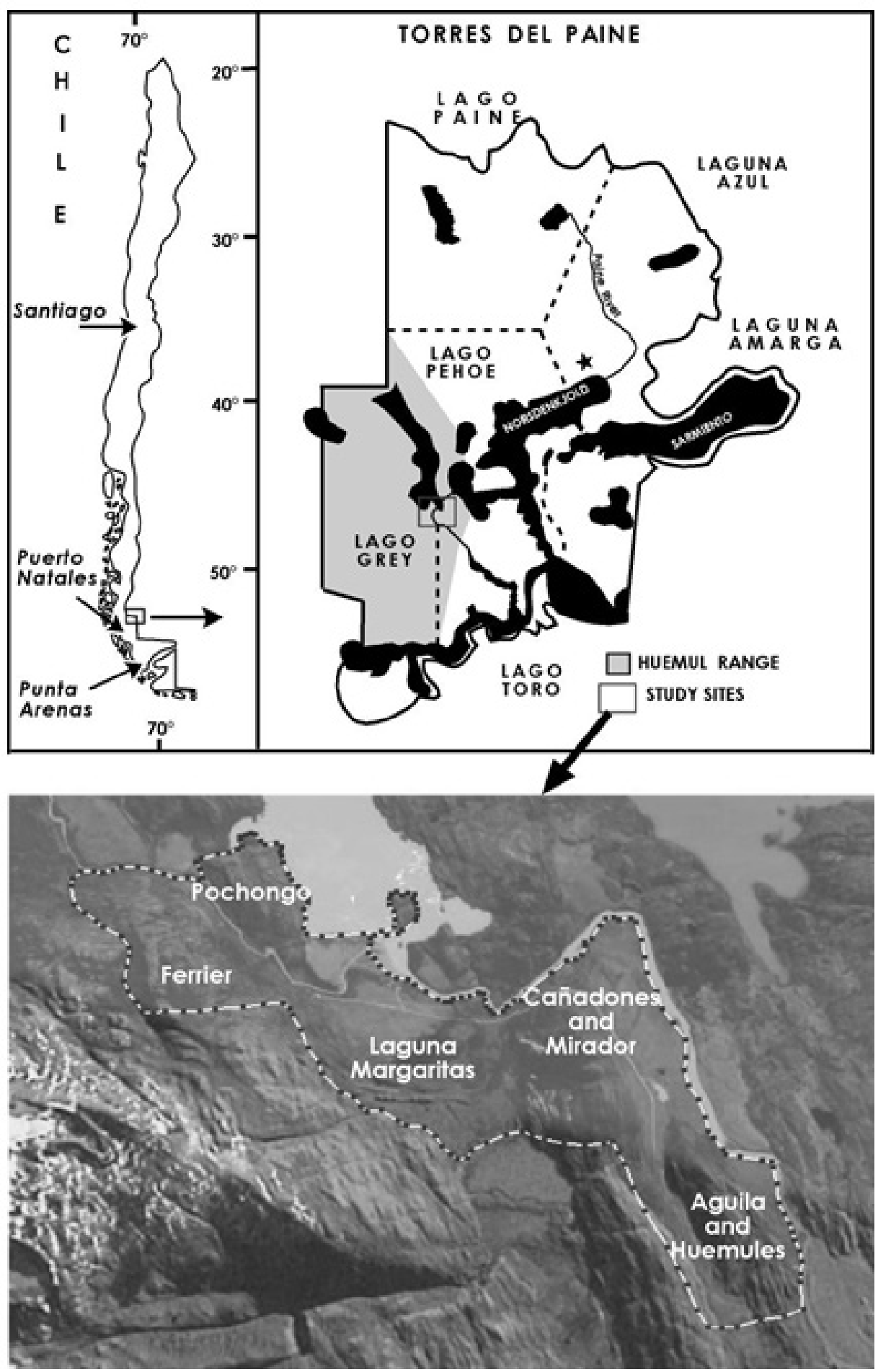

Fig. 1. Location of the study area at Torres del Paine National Park, Magallanes, Chile. The dotted line shows the boundaries of the study site (Source: Google Earth ${ }^{1} 2013$, Image (C) 2016 CNES/Astrium). 
groups that were closest to the last point of vehicular access in the area of Lago Grey. This is a vast area with a very broken topography of about $375 \mathrm{~km}^{2}$. Our study site covered approximately $23 \mathrm{~km}^{2}$ that included five areas, a) Mount Ferrier (300 ha), b) Pochongo Hill (296 ha), c) Moraine Margaritas (367 ha), d) Cañadon and Mirador Hills (314 ha), and e) Huemules and Eagle Hills (319ha) (Figs. 1 and 2). From 2001 onwards the Ferrier area was eliminated because it was the most difficult to access $(600 \mathrm{~m}$ climb to cover approximately $300 \mathrm{ha}$ ).

Topographically the study area is very uneven because of the great orogenic activity and glacialfluvial action, containing many inclined rocky slopes and moraines. It is located on the Trans-Oceanic ecological region and the Andean region (DiCastri, 1968) and has an average precipitation of 800 to $850 \mathrm{~mm}$ per year. It can be included within the range of the Eastern pre-cordillera with Magellan vegetation of deciduous and mixed deciduous/ perennial forests (Pisano, 1974). Its periglacial location has suffered the colonizing human influence for nearly 100 years, manifested in large forest fires to open grazing areas, which has generated the presence of patches of bushes of various sizes among the open and forested areas.

The dominant tree species in the area are lenga (Nothofagus pumilio) and coigüe ( $N$. betuloides), with some ñirre ( $N$. antarctica) in valleys and small, stunted trees in the upper levels of the mountain. There are dense patches of mesophyte shrubs including ciruelillo (Embothrium coccineum), leñadura (Maytenus magellanica), calafate (Berberis buxifolia), baccaris (Baccharis magellanica), chaura (Gaultheria mucronata) and myrtle (Empetrum rubrum). The lack of grazer species has allowed grasses to prosper in most of the area. Some of the most abundant grasses and herbs include common velvet grass (Holcus lanatus), orchard grass (Dactylis glomerata), bunch grass (Festuca spp.), dandelion (Taraxacum officinale), clover (Trifolium repens), seven veins (Plantago lanceolata), wild pea (Lathyrus magellanicus) and Lord Anson's pea (L. nervosus).

\section{Data collection and analysis}

The study period included Nov 1999 to Nov
2009. From 1999 to 2003, a permanent route was visited on a monthly basis to assess the number of huemuls in the area, and to help us determine the best areas for long periods of observation of known groups. We continued monitoring the huemul on a bi-monthly visits from 2004 to 2006, then we monitored the huemul every three months from 2007 to 2009.

In each visit to the study site we walked through the five areas using the established route in search of huemuls. Animals were detected by constantly scoping the area aided with long-range binoculars (Tasco 10x-30x 50). It took several hours to several days to find the huemuls due to the challenging environmental conditions and extended area of the study site, which included dense vegetation, rough topography and soil conditions, presence of snow or rain, constant Patagonian wind, and the low density of animals.

To determine the social structure, we recorded the composition (number of animals, sex and age) of the groups found and established their geographic position with a Garmin GPS Plus. This data helped us to verify the animal movements in the area. To establish behavioral patterns, we conducted intensive observations between 2004 and 2006. Once a group was located, we observed it for at least three consecutive days to collect behavioral data. Since huemuls in the park are not afraid of humans, we were able to observe within 20 meters of them. We retreated if we felt that were interfering with the behavior of the group of animals. If we had to move because we could not observe them on a constant basis, such as if the group moved in and out of a forest patch, we suspended the observation until we were able to constantly see the group. No animals were followed into the forest to avoid causing them stress, thus all observations were done in the open.

To identify the individual animals, we recorded natural marks or scars on their bodies, coloring of body and face, and shape and length of antlers in males. We also ear-tagged 16 fawns (10 females and 6 males) from 2002 to 2008 (Permits were obtained from the Servicio Agricola y Ganadero, SAG - Chile). This was done without the use of immobilizing drugs. This type of capture was based on experience obtained by the co-authors while trapping guanaco chulengos at Torres del 


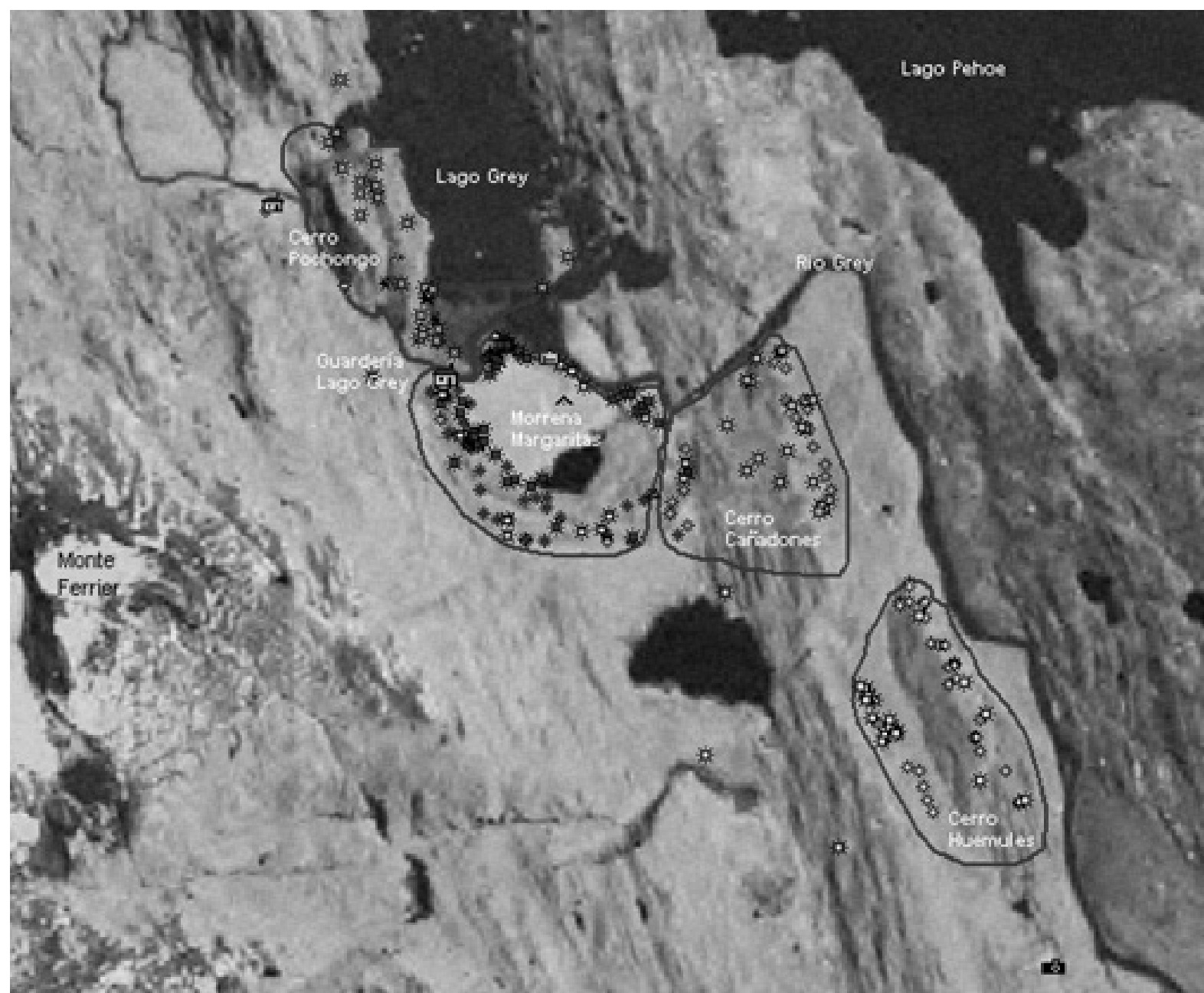

Fig. 2. Encircled areas show huemul main study sites at Lago Grey Sector in Torres del Paine National Park, Magallanes, Chile. Each dot represents a group observed at different times. (Source: Google Earth 2013, Image (C) 2016 CNES/Astrium).

Paine National Park in the mid-1980's, and also based on Ortega's experience with trapping whitetailed deer fawns in his doctoral research project in Texas, USA, in the late 1980's. Pictures were taken of every animal observed from 2002 to 2009. This allowed us to identify 47 huemuls during the study: 11 females, 15 males, 5 yearlings and 16 fawns. Although huemul fawns do not have white spots, they are easily recognized by size (up to 11 months). Similarly, yearlings between, 12 and 24 months were recognized by their size. Males were recognized by the development of their antlers. We identified young males from two to three years of age by their slightly smaller antlers and thinner bodies as compared to adult males.
To better understand the social interactions between the group members, agonistic and antagonistic behavior were recorded. These observations included communication by physical contact, vocal communication, play and aggressive behavior or chases.

Analysis of variance in which significant differences between means were determined by the "protected LSD" (Least Significant Difference) multiple comparison procedure was used to analyze the data (Snedecor \& Cochran, 1989), using JMP Statistical Software ${ }^{2}$ (1989-2007). All significant levels are reported from two-tailed statistical analysis. We calculated group home ranges using a minimum convex polygon (MCP) (Mohr, 1947) 
and modified vertexes edit method (Hooge \& Eichenlaub, 1997) with the program OziExplorer ${ }^{3}$ (2009) and Google Earth 2013).

\section{RESULTS}

In the ten-year study 75 observation episodes were done in 370 field days. Three of these years were used to collect behavioral data, which resulted in 4,106 focal observations of 15 min per animal, giving a total of 61,590 minutes of observations (1,026.5 hrs).

\section{Social structure}

Throughout the study period, we did 472 field observations on various huemul groups. We identified two main categories of huemul groups: established and transient. Among the established groups we observed: a) family groups, usually a male and a female, with or without yearlings and fawns, ranging between two to four individuals; b) solo female, with or without fawn/yearlings, can be the female pre/post-parturient; c) solo male, usually it was the territorial male in his home range when the female was giving birth or elsewhere within the home range. Among the transient individuals we observed: a) mixed group, usually groups of more than four individuals from both sexes and different ages during the fall/winter, with a maximum of seven individuals seen; b) solo female, these were females that had not been observed in the area before and tended to remain for a short period of time, usually a week or so if they gave birth; c) solo male, these were males not seen in the area before and usually were seeking for a place to establish a territory; d) solo yearling; and e) pair of yearlings. The latter two groups were temporarily or definitively out of a family group.

Of 388 groups observed, $74 \%$ were in established groups, $52.6 \%$ were in family groups, followed by $11.8 \%$ in solo female and $9.6 \%$ as solo male, while the transient groups ranged from $1.7 \%$ to $7.5 \%$ (see Table 1). There was a significant difference among the established family group and the rest of the groups

2 JMP Statistical Software. (1989-2007). Version 7. SAS Institute Inc., Cary, NC.
$(\mathrm{P}<0.0001)$. Although there is no monthly difference on the presence of established family groups ( $P>0.0001)$ their percentages as part of the whole vary from $29.6 \%$ in Oct to a $72.7 \%$ in Feb (Table 1). The established family groups were observed in low numbers starting in Oct until Dec, which when females typically give birth. During this period many of the females in family groups look for a more secluded place to either give birth or to keep the fawn for a couple of weeks. The established solo male were territorial males walking about in their territories by themselves, hence in some periods other than the birthing season they were seen around by themselves, for example in Jan, Mar, and Aug (see Table 1).

Among the transient groups, there were several individuals that came into the study area, including adult females, adult males, and some juveniles (Table 1). Transient yearlings were common during the birthing season when pregnant females or females with fawns expelled them from their birth group. Although some of the yearling males were also seen from February to May looking for areas with groups that would accept them.

\section{Home range}

There were four family groups established in the study site, each in an area with an average of 309.9 ha (S.D. \pm 28.6 ha; about $3 \mathrm{~km}^{2}$ per group). The family groups usually remained in the same area. The density in these areas ranged from 0.65 to 1.29 huemul $/ \mathrm{km}^{2}$ depending on whether there were two or four animals in the area (with or without fawn or yearling). In the fall, however, the density reached 2.26 huemul $/ \mathrm{km}^{2}$ in areas with groups of 7 animals (Fig. 2).

The group home ranges varied from 269.6 to 336.7 ha (Fig. 3). The home range borders were based on the local topography, including natural boundaries such as rivers and ravines. Home range overlap was more noticeable in fall and winter, when groups on the high mountains came down due to the snow. The home range seems to be the same as the territory since the established males

3 Oziexplorer (2009). GPS mapping software, version 3.90.3a. D\&L Software Pty Ltd, Australia. 
Table 1. Huemul group monthly percentage at Torres del Paine National Park, Nov 1999 to Dec 2009.

("--" indicates that no such a group was seen that month).

\begin{tabular}{lccccccccc}
\hline & \multicolumn{7}{c}{ Established } \\
& Family & Solo & Solo & Mixed & Family & Solo & Solo \\
& Group & Female & Male & Group & Group & Female & Male & Yearling & Yearlings \\
\hline Jan & 51.7 & 13.8 & 10.3 & -- & -- & -- & 6.9 & 10.3 & 6.9 \\
Feb & 72.7 & 9.1 & -- & 9.1 & -- & -- & -- & 9.1 & -- \\
Mar & 53.3 & -- & 13.3 & 20.0 & -- & -- & 6.7 & 6.7 & -- \\
Apr & 60.0 & 4.0 & 8.0 & 4.0 & 4.0 & 4.0 & 4.0 & 12.0 & -- \\
May & 70.6 & 5.9 & 5.9 & -- & 5.9 & -- & 11.8 & -- & -- \\
Jun & 66.7 & 4.8 & 9.5 & 4.8 & 9.5 & -- & -- & 4.8 & -- \\
Jul & 47.8 & 21.7 & 8.7 & 13.0 & 4.3 & -- & 4.3 & -- & -- \\
Aug & 50.0 & -- & 12.5 & 25.0 & -- & -- & 12.5 & -- & -- \\
Sep & 66.7 & 8.3 & 8.3 & 8.3 & -- & 8.3 & -- & -- & -- \\
Oct & 29.6 & 29.6 & 11.1 & 3.7 & 7.4 & 11.1 & 3.7 & -- & 3.7 \\
Nov & 31.3 & 25.4 & 16.4 & 1.5 & 3.0 & 6.0 & 4.5 & 6.0 & 6.0 \\
Dec & 30.8 & 19.2 & 11.5 & -- & 3.8 & 7.7 & 7.7 & 15.4 & 3.8 \\
\hline Average & $52.6^{\mathrm{a}}$ & $11.8^{\mathrm{b}}$ & $9.6^{\mathrm{b}}$ & $7.5^{\mathrm{b}}$ & $3.2^{\mathrm{b}}$ & $3.1^{\mathrm{b}}$ & $5.2^{\mathrm{b}}$ & $5.4^{\mathrm{b}}$ & $1.7^{\mathrm{b}}$ \\
\hline
\end{tabular}

Note: numbers with different letters between columns show significant difference $(\mathrm{P}<0.0001)$

defended the home range and females actively throughout the year.

Reproductive season

The reproductive season starts with the rut at the beginning of the fall, usually late February to early April. The established male will mate with usually one female in his home rage. Most mating was seen in late March and early April. We were not able to determine the age of the first mating for males, because the marked males left the study site at about a year and a half of age. The first mating in the marked females was when they were about 16 months old. Females gave birth from late October to early November. Of the four marked females that stayed in the study area, female 459 did not get pregnant during the three years we observed her as an adult. The other females had fawns every year until the end of the study, except in 2007 when females 465 and 471 were not pregnant; these females were seen with fawns at seven years of age in Nov 2010. As an update from 2015, female 471 (12 years old) had a fawn in Nov 2015, keeping it in the same territory. Female 462 (9 years old) was still in her territory with no fawn, while female 798 (13 years old) was seen with a male, but no fawn, in the area Pingo, about $10 \mathrm{~km}$ northwest from where it was marked.

\section{Social behavior dynamics throughout the year} Adult male-female interactions

The most evident interaction between males and females was during the rut. Part of the mating was observed in 2005 when the female 459 coupled with a male. In 2003 and 2004 full copulations were observed in the family group that lived in the Margaritas area.

To initiate mating, the male touched the female several times from the tail to the head, with a quiet groaning while trying to mount her. She usually moved away, but eventually she accepted the mount. In other occasions we observed that the behavioral sequence started from the area where the female had urinated. The male approached 

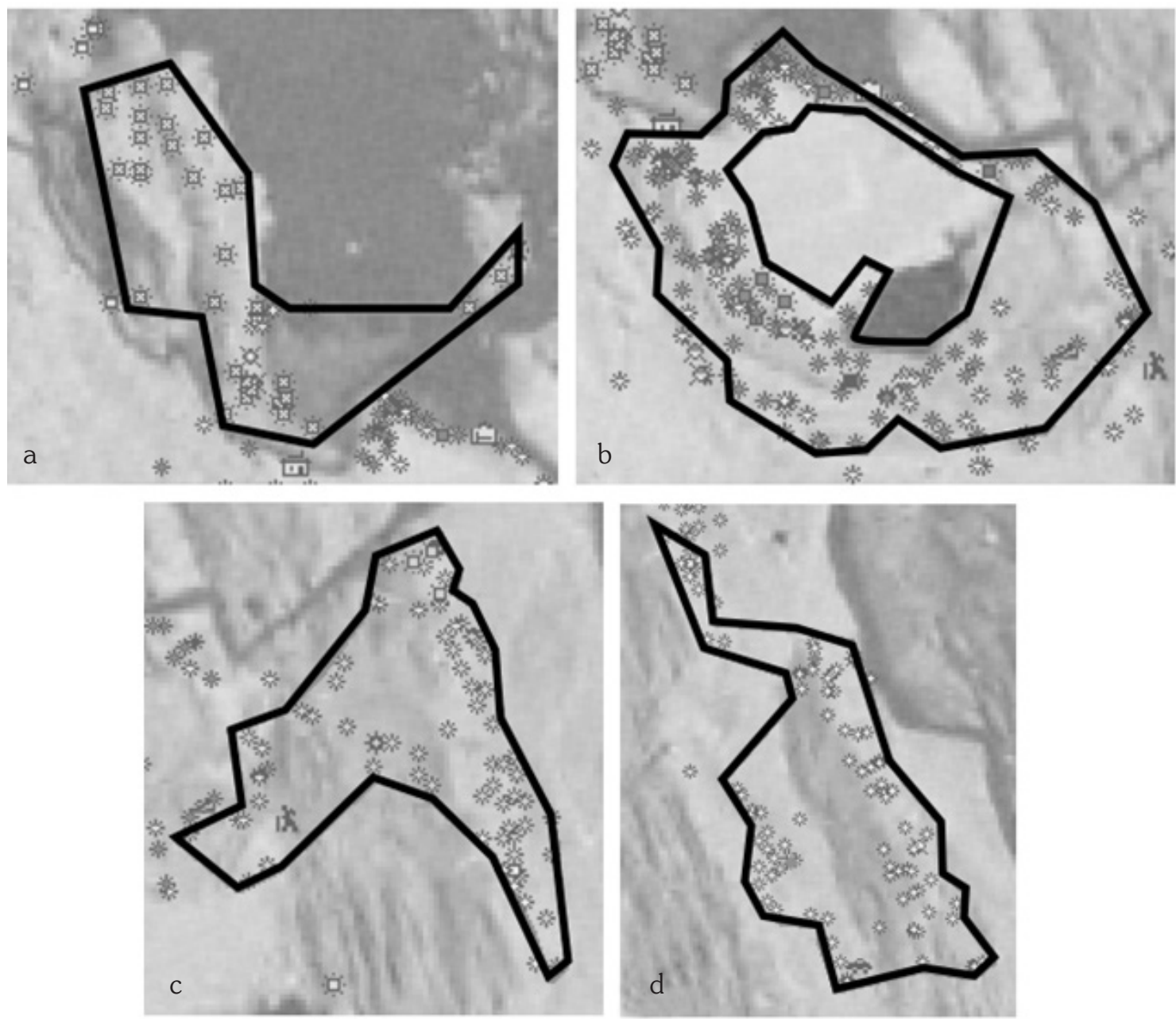

Fig. 3. Home range of known huemul family groups at Torres del Paine National Park, Magallanes, Chile. a)

Pochongo hill (269.6 ha); b) Margarita moraines (336.7 ha); c) Cañadones and Mirador hills (314.2 ha); and d) Huemul and Aguila hills (319.1 ha). (Source: Google Earth 2013, Image (c) 2016 CNES/Astrium).

the area, smelled the urine and did a typical deer flehmen position (as described by Estes, 1972). Then the male moved quickly towards the female, smelled her, licked, and mounted her.

The only other type of interaction commonly observed between a male and females was when they rested together. In several occasions we observed either the male or female lay down first then the other individual lied down close by, spending time ruminating or sleeping.

In Patagonia the wind eliminates most sounds, however, we heard some vocal communication between males and females, mostly very soft groaning. If a female, while browsing, got too closed to the observers, the male would grunt softly.

\section{Adult male-male interactions}

The presence of a foreign male in or near the home range produced stress to the established male throughout the year. If an intruder male was seen inside of the established male's home range, the established mail would do a territorial display. If the intruder male was near a female, the territorial display became more aggressive, especially in the rut season. The displayed antagonistic behavior included snorting, stomping, and trashing bushes. Usually this display was enough to drive off intruder males. In two cases the intruder male did not move away from the area and the established male chased it to the boundaries of the home range. 
Observations of fighting were rare during the rut due to the low population. Only two observations in ten years included a confrontation with direct contact. In the two observed cases in which the males interlocked antlers, they did so for about 4 to 7 minutes and the strongest stayed in the area. In the first encounter observed, the males interacted for less than a half a day. However, in the second observed case the males interacted in this way for three consecutive days. In both cases the bigger male with larger antlers was the one that remained in the area, while the other one moved out.

\section{Dynamic group interaction during fawning season}

Pregnant females became more aggressive during the fawning season. They became solitary when giving birth and remained isolated for about two weeks after the birth of the fawn. The yearlings moved away from the family group after being expelled by both the female and the male between two weeks and a month before the parturition. The female avoided the male; so all three members of the group were seen alone during this period, dispersed within their own home range. The yearling often remained in the vicinity alone or joined another juvenile, but some of them left the area definitively.

As with many other deer species, the huemul fawn hid for the first two weeks of its life. Once the fawn was stronger, it followed its mother to join the male and the yearling. The yearling and the male briefly visit the female and her fawn several times for about three to four weeks after the fawn's birth. Once the female was ready, she and the fawn joined the male and the yearling to become a family group again.

\section{Fawn interactions}

The most evident interaction between huemuls was between mother and fawn. These interactions were most evident in the first months of a fawn's life. These observations were made easier because of the marked fawns over the following years: in 2002 fawn 763 and her mother; in 2003 fawns 459, 465, and 471; in 2005 fawns 52 and 55; in 2006 fawn 462; in 2007 fawn 70; and in
2008 fawn 66. Observations were also done on 465 and 471 as mothers and their respective fawns, which were also marked (Table 2).

Females maintained constant contact with the fawn by smelling, touching, and licking it. During the lactating period the females licked their fawns' anal region to stimulate defecation and urination, as observed in other deer species. When the huemul fawn hid, the female searched for it to allow lactation. The mother ended the nursing period ( $100 \%$ of the observations done). Only few nursing events were seen due to their secretive behavior.

Once the fawns started to follow their mothers and explore their surroundings the communication became vocal. If a fawn could not see its mother, it would make a "baah" sound and the mother would respond in a similar fashion and move to where the fawn could see her.

Fawns also interacted with other members of the group, usually through play, by running together or mounting their relatives. The fawn's interaction with the male usually was different. If the male was standing up there was little interaction, but if the male was laying down the fawn interacted with the male by rubbing his head, although the male usually did not react. In these cases, the fawn quickly tired of the male's inactivity and moved away.

In two cases where fawns were killed by puma (Puma concolor), the female remained close to the fawn carcass for about three days before moving out of the area. Although the puma may have been nearby female huemuls did not show fear of staying in the area.

\section{Yearling interactions}

Yearling interactions with the adult female and adult male during the birth season as mentioned above were seen between October to November. We were able to observe the expelling behavior during that period in marked animals, in 2003 with yearling 763, in 2004 with yearling 459, in 2005 with yearling 55, and in 2007 with yearling 462. The expulsion behavior consisted of an adult chasing a yearling within the territory, once they stop, the adult male, remains at a certain distance, moving its head sideways towards the yearling. The yearling sometimes insisted on coming back, 
but usually left the area without much resistance. It remained nearby, out of the adult's sight.

Once the yearlings moved out, some paired up with another yearling, male or female, for a short period. This was observed on four occasions: Pochongo Hills in Nov 2001 and Sep 2003, Margarita moraine in Feb 2005, and in Cañadones hills in Jan 2007. Females 459 and 471 were seen as a pair for a period of time, and on several days they were also seen with a male yearling.

During the times when the yearlings were paired, they played together, touching each other and running together. In the case of two males, they stayed together until they were two years old. By that time they were seen doing some play fighting by interlocking their antlers.

Almost all of the yearlings returned to the group after two or three weeks, to spend the rest of the summer and winter within the family group before moving out into another home range. In the fall of 2005, an adult female with her yearling male and a second yearling male joined the Margarita moraine family group (group recognized because the marked female yearling 471). On this occasion, the established male expelled the solo yearling male several times. However, the yearling male was persistent and remained at a distance, slowly moving back into the home range and later staying in it, but maintaining his distance to the adult male. When the yearlings were finally accepted back into their corresponding groups, these individuals interacted with the fawn by playing, charging, or running. They were also seen interacting with the female by either laying down close to her or walking alongside. In a different case, a yearling male was seen interacting with the adult male by rubbing his head and antlers over the male's head and antlers, which the adult male allowed. In a different family group, two-year-old marked female 471 lost her own fawn and stayed with her mother's group. The mother of female 471 gave birth a female fawn (ear-tagged number 55); so female 471 had a sister. That winter their mother died and female 471 cared for her sister.

\section{Group dynamic}

We observed the group dynamic of the huemul over the years, such as animal movement within or in-between groups that can be described as: home range, reproductive, social and seasonal movements.

\section{Home range movements}

Established family groups in the area moved within their home range exclusively. When the family group moved within the home range it was the female that acted as the leader in $100 \%$ of all observations of movements of family groups. The male always stayed from two to twenty meters behind. The family groups remained up to five days in the same area, which was the maximum value recorded in all observations. Once the group decided to move, it usually moved between 500 to 1,000 meters. On a monthly basis these groups covered the whole home range, without any specific routine on the sites used.

\section{Reproductive movements}

This type of movement was related mostly to the females in the late stages of their pregnancies. It was at this time that females that lived on the slopes of hills moved down to the valleys. These movements were observed from October to January (Table 1). In the flats of Margarita moraine, we observed new females that had come into that area to give birth. They stayed for two to three weeks before moving out of the site. Once a male came in with a female and stayed for a brief period before moving out of the area.

\section{Social movement}

As we mentioned before, once the fawns became yearlings, they moved out of the family groups under two circumstances: first during the fawning period and second at the end of winter during their dispersion. We observed the highest numbers for solo yearlings in December (15.0\%) followed by April (12.0\%) and January (10.3\%). Two or more yearlings were seen moving out of the family group often, with the highest average in January $(6.9 \%)$ followed by November $(6.0 \%$; Table $1)$. Transient yearling pairs were seen in different areas, but remained within the home range. These movements were sporadic before the fawning 
season but were more noticeable after the yearlings reached the age of eighteen months. Towards the end of the summer some yearlings usually joined a different family group than its origin, forming a groups that had three yearlings $(9.1 \%$ in February, $20.0 \%$ in March). Later some of these yearlings were seen in mixed groups in the late winter/early spring (Table 1). We did not monitor transient yearlings that moved out of the study site.

Female yearlings 471 and 465 remained with their birth groups for several years without opposition by the adults. This happened because their sister/brother or their own fawn died in the first few months after birth. Both females took their mothers' place in the home range after they died (2006 for 471 and 2008 for 465). Both 471 and 465 were seen still in the same place in January 2011 (Margaritas and Huemuls hill, respectively).

In another case, the brother of the female yearling 459 survived, so she left the area and at one and a half years old she became established with a male about $2.5 \mathrm{~km}$ distant from her natal home range (Cañadones hill area). Similarly female yearling 462 (471's daughter) left her natal home range (Margaritas moraines area) and at one and a half years old she became established with a male located next to her natal home range (Pochongo hill area). Female 459 did not get pregnant the next year after becoming established with Cañadones area male. At that time a transient female with a fawn came into the home range and became very aggressive towards female 459, chasing her constantly until she left the area and the study site.

Although several males were marked we could not follow them out of our large study site. However, we were able to follow several males from yearling on within the study site because of their natural markings, facial coloring, or antler form. We observed seven of these recognizable males establish themselves in the study for three to eight years.

\section{Seasonal movements}

In fall or winter, the family group stayed in close proximity to each other. In some cases a yearling or an adult female, and in few cases an adult male, joined the group, forming a mixed group for a short time. This social group was only seen in the Margarita moraine area, which is located near a very large hill (Ferrier mount). The huemuls that join the established family group came from the high areas of the hills into the lower areas and valleys in the fall and winter. The movement of these animals started as soon as the deciduous trees start dropping their leaves or first snow in the fall or early winter. It was only at this time of the year when mixed groups up to five to seven animals were seen at Margarita moraine, (Jun 4.8\%; Jul $13.0 \%$; Aug 25.0\%, and Sep 8.0\%, Table 1). No mixed groups were seen within the home range of established family groups in the study site.

\section{DISCUSSION}

This ten years project represents a first attempt to obtain long-term data in a protected huemul population. It was the first time that huemuls fawns have been marked for a study in Chile, with a minimal intervention and health risk to them since we did not use drugs. This type of trapping and handling of animals for marking purposes seems to be the most appropriate for a species that is critically endangered. The low density of huemul in the area, along with their sparse distribution was a limiting factor in our observations. However, the length of the study allowed us to see enough repetition of these behaviors. Since we could identify individuals, some of the locations became predictable depending on the season.

The social structure of the huemul in a protected and extensive area, such as Torres del Paine National Park, is based on the family group. This is certainly different for huemul population observed by other researchers (Díaz \& Smith-Flueck, 2000; Frid, 1999; Povilitis, 1983, 1985) with the lack of sexual segregation found in other Cervidae (Hirth, 1977; Main et al. 1996). Patagonian huemul populations studied elsewhere are found in reduced populations within limited areas because human populations surround them. Similar to the populations in Chillan, Chile (Povilitis, 1979), we were able to establish that the huemul have a high fidelity to their birth site, remaining there as long as possible unless expelled by the established males. The density of the population on the study site did not vary much during the study. This is a reflection of how the animals living in these home ranges are able to maintain low numbers by keeping transient 
animals out of them, which it was aided by the dispersion of yearlings into other areas.

This huemul population seems very stable, however we believe that the population in the study site is at its carrying capacity and animals were dispersing to other areas of the park. The density is similar to the one reported in the Rio Negro province, Argentina (Smith-Flueck and Flueck 1997). Perhaps huemuls at the Torres del Paine are at a carrying capacity that will make them defend their home range, making it a territory. Territorial defense has not been reported in Cervidae, which will make the huemul unique in this sense. The lack of migration in this population make us believe that there is plenty of space and enough food resources to avoid moving to other places in times of deficiency. However, we saw an altitudinal short-distance migration of animals from areas where snow cover make the access to food resources difficult.

Females, as reported for other Cervidae, became pregnant early in life, however the births occurred earlier than other huemul populations in other sites (Aldridge, 1988; Montecinos, 1995; Povilitis, 1979). Females secluded themselves during the parturition, behavior that has also been observed in taruca (Hippocamelus antisensis) (Merkt, 1985, 1987). Males in this population tended to be less aggressive and had fewer encounters with other males than what has been observed elsewhere (Povilitis, 1979). This could be related to the low population and potential for animal dispersion to other areas within or outside the park, thus eliminating the need for intruders to try to take over home range already established. The home ranges we have observed averaged 310 ha, and are unaffected by disturbance, unlike other sites (444 to 1954 ha, Gill et al. 2008, or 700 ha, Povilitis, 1985; Díaz \& Smith-Flueck, 2000). Seasonally the individual home range is smaller for example during the fawning period for the females, just as found on a seasonal home range by Gill et all. (2008, 36-82 ha).

Since preexisting studies have all been shortterm and covering only certain seasons, literature concerning male-female interactions throughout the year is limited. In our study the interaction seen among the members of the family group was constant throughout the year. This allowed us to observe how females tended to stay with their mothers as long as no sister or brother survived, otherwise they moved as close as possible to their birth home range. Perhaps that the stability of being in a secure and known place keep the animals from migrating, as we observed with four marked females and seven naturally marked males.

Due to budget restrictions, we were unable to use radio or GPS collars to gain additional information about the movements of huemul we studied. We were also unable to use genetic information. This information could help us to better understand the potential for inbreeding in this small population. Genetic work must be considered in a near future.

\section{Management Implications}

The knowledge acquired in this long-term project will help the Torres del Paine National Park in the management of the small huemul population, and perhaps more importantly help them to educate the many tourists that hike through the area every year on the importance of not disturbing this endangered species. It is critical to inform the tourist to stay away from areas where the huemul live and to maintain a certain distance from these animals during the mating and fawning seasons, March-April and October-January, respectively. There is also a critical need to monitor transient animals to better understand how the huemul is starting to spread within the park. This monitoring could provide information about the marked animals that moved out of the study site. The presence of huemul towards the northeast, east and south of the area has being confirmed by the park rangers and tourists, but not all of the exact locations have been provided, nor the exact number of animals or their age or sex, thus the sightings have not been recorded. This type of information could help managers to understand if the population is on the increase or not. Although hunting pressure from the puma has not produced a major impact on the huemul population in our study site, we need to know if this predator is impacting the animals that disperse elsewhere.

The huemul, as species, is a Chilean national symbol, and as such many tourists get too close to them in order to take a picture. Our study shows 
that most family groups tend to stay in the same area for a long period of time, which increases their fitness. Interruption in the social behavior could bring dire consequences for the established huemul residents, which will move away. Although, based on our observations, empty home ranges do not stay empty long. The many transient yearlings and adult solo males were always waiting for the opportunity to claim an open home range.

Finally we have to agree with Frid (1999) on his statement that the loss of the huemul is not only a loss of a species, but represents a substantial loss to the diversity of Cervidae. Chile has only three species of Cervidae: taruca, pudu (Pudu puda) and huemul. The loss of one of them is a mayor loss for the diversity of this family in this part of the planet. Of the three, huemul is the only species in the Patagonian region south to Aysen.

\section{ACKNOWDLEGEMENTS}

We would like to thank many of the supporting organizations that made this work possible, among them: UConn Patagonia Expeditions, Hotel Lago Grey, and Hotel Las Torres. We especially thanks to the local park ranger of the Sector Lago Grey, Mr. Fredy Barrientos, who has dedicated a large portion of his life to study and protect the huemul population in the area. We also would like to thank the many volunteers involved, including C. Carmona, B. López, J. Sotomayor, C. Torres and some of the field guides from the Hotel Lago Grey and Hotel Las Torres, and UConn students participating in the UConn Patagonia Expeditions. We also would like to thank the logistic support from the hotel's administrators and managers: J. Salas, J. Gutiérrez, D. Seron, L. Kusanovic, V. Méndez, C. Soto, and C. Morales. We also would like to thanks Andrea Petrullo and two anonymous reviewers for making this manuscript more understandable.

\section{LITERATURE CITED}

Aldridge D. K. (1988). Proyecto conservación del huemul (Hippocamelus bisulcus) en Chile. Medio Ambiente. 9, 109-116.

Anonymous. (2006). Resultados de la 5ta. Reunión Binacional Argentino-Chilena, sobre
"Estrategias de Conservación del Huemul", El Chaltén, Prov. De Santa Cruz 24 - 27 de abril de 2006

Colomes A. A. (1978). Biología y ecología del huemul Chileno (Hippocamelus bisulcus). Estudio de sus hábitos alimentarios. Disertación. Universidad de Chile.

Díaz, N., \& Smith-Flueck, J. (2000). El huemul Patagónico: un misterioso cérvido al borde de la extinción. L.O.L.A., Monografía N³. Bs. Aires, Argentina.

Di Castri, F. (1968). Equisse ecologique de Chili. Biol. De l' Amerique Austral. Paris, 4. Centre Nat. De Rech. Scient.

Drouilly, P. (1983). Recopilación de antecedentes biológicos y ecológicos del huemul Chileno y consideraciones sobre su manejo. CONAF. Boletín Técnico, 5, 1-57.

Estes, R. F. (1972). The role of the vomeronasal organ in mammalian reproduction. Mammalia, 36, 315-341.

Flueck, W. T.. \& Smith-Flueck, J. (1993). Current status and conservation of huemul in Argentina. Final Report to the Wildlife Conservation Society, Bariloche.

Flueck, W. T., \& Smith-Flueck, J. (2006). Predicaments of endangered huemul deer, Hippocamelus bisulcus, in Argentina: a review. Eur $J$ Wildl Res, 52, 69-80

Flueck, W. T. (2009). Exotic deer in southern Latin America: what do we know about the impacts on native deer and on ecosystems? Biological Invasions, 12, 1909-1922.

Frid, A. (1999). Huemul (Hippocamelus bisulcus) sociality at a periglacial site: sexual aggregation and habitat effects on group size. Canadian Journal of Zoology, 77, 1083-1091

Gill, R., Saucedo Galvez, C., Aldridge, D., \& Morgan, G. (2008). Ranging behaviour of huemul in relation to habitat and landscape. Journal of Zoology, 274, 254-260.

Guineo, O., Garay, G. \& Guineo, R. (2008). Conociendo al huemul de Torres del Paine. Talleres del la Prensa Austral.

Hooge, P. N., \& Eichenlaub, B. (1997). Animal movement extension to ArcView. Version Alaska Biological Science Center, U.S. Geological Survey, Anchorage, Alaska, 
USA.

Hirth, D. H. (1977). Social behavior of whitetailed deer in relation to habitat. Wildlife Monograph, 53, 1-54.

Jiménez, J., Guineo, G., Corti, P., Smith, J. A., Flueck, W., Vila, A., Gizejewski, Z.,... Geist, V. (2008). Hippocamelus bisulcus. In IUCN 2010. IUCN Red List of Threatened Species. Version 2010.4. URL: http:// www.iucnredlist.org.

Main, M. B., Weckerly, F. W., \& Bleich V. C. (1996). Sexual segregation in ungulates: new directions for research. Journal of Mammals, 77, 449-461.

Merkt, J. R. (1985). Social structure of Andean deer (Hippocamelus antisensis) in southern Peru. M.Sc. thesis, University of British Columbia. Vancouver.

Merkt, J. R. (1987). Reproductive seasonality and grouping patterns of the north Andean deer or taruca (Hippocamelus antisensis) in southern Peru. In C.C. Wemmer (Ed.), Biology and management of the Cervidae (pp. 388-401). Smithsonian Institution Press, Washington, D.C.

Mohr C.O. (1947). Table of equivalent populations of North American small mammals. American Midland Naturalist, 37, 223-249.

Montecinos, L. (1995). Estudio biológico y etológico del huemul. Sector Rio Claro 1984-1994. CONAF XI Región. Coyhaique, Chile.

Pisano, E. (1974). Estudio ecológico de la región continental sur del área andino-patagónica.
II Contribución a la fitogeografía de la zona del Parque Nacional Torres del Paine. Anales del Instituto de la Patgonia, 1-2, 59-103.

Povilitis, A. (1979). The Chilean huemul project: huemul ecology and conservation. Ph.D. Thesis. Colorado State University, Fort Collins, Colo.

Povilitis, A. (1983). Social organization and mating strategies of the huemul (Hippocamelus bisulcus). Journal of Mammals, 64, 156158.

Povilitis, A. (1985). Social behavior of the huemul (Hippocamelus bisulcus) during the breeding season. Z. Tierpsychol, 68, 261286.

Rau, J. (1980). Movimiento, habitat y velocidad del huemul del sur. Notas mensuales. Museo Nacional de Historia Natural, Chile. 282, 7-9

Smith-Flueck, J. M., \& Flueck W. T. (1997). Survey of a huemul population in the province of Rio Negro, Argentina. Journal of Neotropical Mammals, 4, 25-33.

Snedecor, G. W., \& Cochran, W. G. (1989). Statistical Methods. Iowa State University Press, Ames, IA.

Vila, A. R., Lopez, R., Pastore, H., Faundez, R., \& Serret, A. (2006). Current distribution and conservation of the huemul (Hippocamelus bisulcus) in Argentina and Chile. Mastozoología Neotropical, 13 (2), 263269. 